\title{
Acute Phase Response and Neutrophils: Lymphocyte Ratio in Response to Astaxanthin in Staphylococcal Mice Mastitis Model
}

\author{
Tshering Dolma, Reena Mukherjee, B. K. Pati, and U. K. De \\ Division of Medicine, Indian Veterinary Research Institute, Izatnagar, Uttar Pradesh 243122, India \\ Correspondence should be addressed to Reena Mukherjee; drbapai1959@gmail.com
}

Received 12 June 2014; Revised 29 September 2014; Accepted 3 November 2014; Published 19 November 2014

Academic Editor: Fulvio Riondato

Copyright (C) 2014 Tshering Dolma et al. This is an open access article distributed under the Creative Commons Attribution License, which permits unrestricted use, distribution, and reproduction in any medium, provided the original work is properly cited.

\begin{abstract}
The purpose of the study was to determine the immunotherapeutic effect of astaxanthin (AX) on total clinical score (TCS), Creactive protein (CRP), and neutrophil : lymphocyte ratio in mice mastitis model challenged with pathogenic Staphylococcus aureus. Twenty-four lactating mice were divided in 4 equal groups: group I mice served as normal healthy control, group II, positive control, were challenged with pathogenic S. aureus, group III mice were challenged and treated with AX, and group IV were treated with amoxicillin plus sulbactum. The TCS was higher in postchallenged mice; however it was significantly higher in group II untreated mice as compared to group III and group IV mice. The neutrophil was higher and lymphocyte count was lower in group II mice at $120 \mathrm{hrs}$ post challenge (PC). The CRP was positive in all the challenged group at $24 \mathrm{hrs}$ PC, but it remained positive till $120 \mathrm{hrs}$ PC in group II. The parameters are related to enhancement of the mammary defense and reduction of inflammation. Hence AX may be used alone or as an adjunct therapy with antibiotic for amelioration of mastitis. Development of such therapy may be useful to reduce the antibiotic burden in management of intramammary infection.
\end{abstract}

\section{Introduction}

Bovine mastitis is the inflammation of the mammary gland frequently resulting from Staphylococcus aureus colonization in the mammary parenchyma causing high economic losses despite intensive research and preventive measures [1]. In vitro antibacterial sensitivity of commonly used antibioticswas demonstrated by several researchers for $S$. aureus isolates [2]; however the pathogen remains difficult to eradicate with the available antibiotics. Failure in treatment could be due to nonavailability or weak penetration of the antibiotics as the organism survives intracellularly. The greatest demerits of antibiotic treatment are the development of multiple drug resistant bacterial strains and residues in the milk which possess human health hazard. World Health Organization [3] emphasizes need of judicial use of antimicrobials to combat antimicrobial resistance and also to encourage the development of novel preventive and therapeutic aids. Hence search is going on globally for an alternative to antibiotic, or to reduce its dose and duration for therapy. Astaxanthin (AX) is a xanthophyll carotenoid, predominantly of marine origin and naturally obtained from the chlorophyte algae Haematococcus pluvialis [4]. Astaxanthin is a highly potent antioxidant apart from it, it anti-inflammatory, immunomodulatory and antibacterial activities [5-8]. Therefore, the present study was undertaken to determine the effect of AX on acute phase protein, neutrophils : lymphocyte ratio, histopathological changes, and clinical recovery in murine staphylococcal mastitis model.

\section{Materials and Methods}

2.1. Antibiotic Sensitivity Test (ABST) and Minimum Inhibitory Concentration (MIC) of AX. Astaxanthin was procured from a reputed pharmaceutical company (Zenith Pharmaceuticals, Bangalore, India). Ten mg powder was reconstituted in $10 \mathrm{~mL}$ sterile saline solution (NSS), filtered through membrane filter $(0.22 \mu \mathrm{m}$ pore size), and stored in sterile vials. ABST of astaxanthin was done by the disc diffusion method as described by NCCLS [9] against pathogenic Staphylococcus aureus isolated from mastitis milk samples and the standard 
TABLE 1: Therapeutic plan of astaxanthin (AX) in lactating mice challenged with pathogenic Staphylococcus aureus.

\begin{tabular}{|c|c|c|c|c|c|c|}
\hline Groups & Number of mice & Treatment & Dose & Frequency & Route & Interval \\
\hline Group I & 6 & Normal healthy mice & - & - & - & - \\
\hline Group II & 6 & Positive control & - & - & - & - \\
\hline Group III & 6 & $\mathrm{AX}^{*}$ & $16 \mathrm{mg} / \mathrm{kg}$ body weight & Twice daily & Orally & $\begin{array}{l}\text { Oral drenching of AX } \\
\text { for } 5 \text { days PC twice a } \\
\text { day }\end{array}$ \\
\hline Group IV & 6 & Antibiotic $^{* *}$ & $12.5 \mathrm{mg} / \mathrm{kg}$ body weight & Twice daily & Intramuscular & $\begin{array}{l}5 \text { days post } \\
\text { challenge/twice a day }\end{array}$ \\
\hline
\end{tabular}

$\mathrm{AX}^{*}$ was drenched orally after reconstitution in sterile normal saline solution, at the rate of $16 \mathrm{mg} / \mathrm{kg}$ body weight 10 days prior to challenge and continued 5 days post challenge.

${ }_{* *}^{*}$ Amoxicillin + sulbactam-via intramuscular route, at $12.5 \mathrm{mg} / \mathrm{kg}$ body weight.

reference $S$. aureus strain (MTCC number 96, Microbial Type Culture Collection, Chandigarh, India). The dose of astaxanthin was calculated by conducting the MIC against Staphylococcus aureus by tube dilution method as described in previous papers $[10,11]$. For oral drenching in mice, the dosage (in $\mathrm{mg} / \mathrm{kg}$ ) was calculated as per the formulae given below:

$$
\text { Dosage }(\mathrm{mg} / \mathrm{kg}) \text { of Astaxanthin }=\mathrm{MIC} \times 20 \text {. }
$$

\subsection{Isolation and Characterization of Staphylococcus aureus.} The dairy cows were screened for mastitis by California Mastitis Test [12]. Isolation and identification of pathogenicorganism from the mastitic milk samples was done as per the standard procedure [13]. The $S$. aureus organism was initially identified on the basis of colony morphology on 5\% blood agar as [14] and later by Gram staining and growth on selective media like mannitol salt agar (MSA) and Baird Parker agar plates and further subjected to coagulase test; in brief, 2 test tubes were filled up with $0.5 \mathrm{~mL}$ of diluted rabbit plasma; to the first tube $0.1 \mathrm{~mL}$ of overnight broth culture of test organism was added and to the second tube $0.1 \mathrm{~mL}$ of sterile broth was added and incubated at $37^{\circ} \mathrm{C}$ for $4 \mathrm{hrs}$ and observed for the coagulation of plasma if positive [14]. Biochemical tests were performed with standard kits (HiStaph Identification Kit, HiMedia, India). However, molecular characterization was not performed. The dose of organism for intramammary challenge was calculated by surface viable count as per the method described elsewhere [15]. Eighteen-hour grown broth culture of $S$. aureus at the rate of $5 \times 10^{5}$ bacteria was taken for challenge in mice in each mammary gland.

2.3. Experimental Design and Procurement of Mice. Healthy adult lactating Swiss albino mice weighing around 30-40 grams were procured from the institute's vivarium, after weaning their pups, maintained in the divisional animal shed, and housed in animal cages, providing ad libitum water and feed, under standard temperature, ventilation, and humidity. The experimental trial was conducted in lactating mice using the left fourth (L4) and right fourth (R4) inguinal mammary gland. The mice were grouped into four groups with 6 mice in each group. Group I mice served as healthy negative control. Group II were challenged with $S$. aureus and served as positive control. In group III, astaxanthin was drenched after reconstitution in sterile normal saline solution at the rate of $16 \mathrm{mg} / \mathrm{kg}$ body weight from 8 days prior to challenge and continued for 5 days PC orally; group IV was treated with amoxicillin plus sulbactam at the dose rate of $12.5 \mathrm{mg} / \mathrm{kg}$ body weight twice daily for 3 days by intramuscular route as depicted in Table 1.

2.4. Challenge of Mice with Pathogenic Staphylococcus aureus. All the mice of group II, group III, and group IV were inoculated with $18 \mathrm{hrs}$ old culture of $S$. aureus via intramammary route at the rate of $5 \times 10^{6}$ bacteria per teat, under general anesthesia with ketamine at $65 \mathrm{mg} / \mathrm{kg}$ and xylazine at $4 \mathrm{mg} / \mathrm{kg}$.

2.5. Total Clinical Scores (TCS). Mammary glands of mice were screened for mastitis by visual examination [16] followed by total clinical score card.

2.6. Collection of Blood for Serum Collection and Hematological Parameters. Around $1 \mathrm{~mL}$ of blood was collected from the mice using micro capillary tubes on day $0,24,72$ and $120 \mathrm{hrs}$ post challenge from retrobulbar venous plexus behind the eyeball taking special care not to damage the ocular membrane structure [17]. Serum separation was done for CRP. Simultaneously thin blood smear was made stained with Giemsa stain for differential leukocyte count (DLC) to determine neutrophil : lymphocyte ratio [18].

2.7. C-Reactive Protein (CRP). C-reactive protein was done in serum using a standard kit (CRP kit, Latex Agglutination Method, Span Diagnostics LTD., Mumbai, India) by the manufacturer's instruction.

2.8. Histopathological Examination. The mice from each of the four groups were sacrificed after 120 hours PC using xylazine-ketamine combination as injectable anesthesia. Mammary glands L4 and R4 were carefully removed from the skin flaps using blunt scissors and were spread onto a prelabeled glass slide without any air bubbles or hair and stored in $10 \%(\mathrm{v} / \mathrm{v})$ formalin and further processed for Hematoxylin and Eosin (H\&E) staining to visualize the histopathological changes in the tissue section. Mice of all 4 groups were 
TABLE 2: Clinical score card of mice at $0 \mathrm{hr}, 24 \mathrm{hrs}, 48 \mathrm{hrs}, 72 \mathrm{hrs}$, and $120 \mathrm{hrs}$ post challenge in posttreated mice (mean \pm SE).

\begin{tabular}{|c|c|c|c|c|c|}
\hline Groups & $0 \mathrm{hr}$ & $24 \mathrm{hrs}$ & $48 \mathrm{hrs}$ & $72 \mathrm{hrs}$ & $120 \mathrm{hrs}$ \\
\hline Group I & $0 \pm .00^{\mathrm{a}, \mathrm{x}}$ & $0 \pm .00^{\mathrm{a}, \mathrm{x}}$ & $0 \pm .00^{\mathrm{a}, \mathrm{x}}$ & $0 \pm .00^{\mathrm{a}, \mathrm{x}}$ & $0 \pm .00^{\mathrm{a}, \mathrm{x}}$ \\
\hline Group II & $0 \pm .00^{\mathrm{a}, \mathrm{x}}$ & $2 \pm .00^{\mathrm{b}, \mathrm{z}}$ & $2.5 \pm .25^{\mathrm{b}, \mathrm{y}}$ & $3.25 \pm .25^{\mathrm{c}, \mathrm{z}}$ & $3 \pm .00^{c, z}$ \\
\hline Group III & $0 \pm .00^{\mathrm{a}, \mathrm{x}}$ & $1.25 \pm .25^{\mathrm{b}, \mathrm{y}}$ & $1.25 \pm .25^{\mathrm{b}, \mathrm{y}}$ & $1 \pm .25^{\mathrm{b}, \mathrm{y}}$ & $.9 \pm .00^{\mathrm{a}, \mathrm{y}}$ \\
\hline Group IV & $0 \pm .00^{\mathrm{a}, \mathrm{x}}$ & $1.25 \pm .00^{\mathrm{b}, \mathrm{y}}$ & $1 \pm .00^{\mathrm{a}, \mathrm{y}}$ & $1 \pm .00^{\mathrm{a}, \mathrm{y}}$ & $.9 \pm .00^{\mathrm{a}, \mathrm{y}}$ \\
\hline
\end{tabular}

${ }^{*}$ Mean values with dissimilar superscripts in the row (a, $\mathrm{b}$, and $\mathrm{c}$ ) and column $(\mathrm{x}, \mathrm{y}$, and $\mathrm{z}$ ) vary significantly at $P<0.05$.

sacrificed at $120 \mathrm{hrs}$ post challenge. Tissue sections of mammary gland of group I lactating mice revealed normal healthy lactating alveoli with no signs of inflammation. In group II mice multiple focal micro abscess predominated by neutrophil and fibrinous exudates in the mammary parenchyma was observed with complete disruption of mammary cellular details. In mice of group III that received astaxanthin, mammary gland was normal with no inflammatory reaction except at the hypodermic adipose tissue and muscularis junction. In group IV mice, the mammary gland tissue section showed relatively less pathological changes as compared to group II. Cellular inflammatory infiltration was mild.

2.9. Statistical Analysis. The data collected on each parameter was analyzed by standard statistical methods. Level of significance was set $(P<0.05)$ by applying Friedman test for total clinical scores. Level of significance was set $(P<0.05)$ by applying two-way ANOVA for DLC, using statistical software SPSS (Version 17).

\section{Results}

3.1. ABST and MIC of Astaxanthin. The zone of inhibition against isolated $S$. aureus was $26 \mathrm{~mm}$ for astaxanthin, whereas it was $32 \mathrm{~mm}$ for amoxicillin. The MIC of astaxanthin was $750 \mu \mathrm{g}$ against isolated $S$. aureus.

3.1.1. Isolation and Biochemical Characterization of S. aureus. The Gram staining revealed characteristic Gram positive cocci arranged in small bunches (Staphylo). Confirmation was carried out by performing biochemical test for Staphylococcus aureus. Organisms showing positive for catalase, maltose fermentation, coagulase positive, haemolysis of blood agar, oxidation fermentation, methyl red and VogesProskauer test were confirmed as S. aureus.

3.2. Total Clinical Scores (TCS). There was no variation in TCS at $0 \mathrm{hr}, 24 \mathrm{hrs}, 48 \mathrm{hrs}, 72 \mathrm{hrs}$, and $120 \mathrm{hrs}$ of observational period in group I mice, whereas in group II, mild inflammation of the mammary glands was observed at $24 \mathrm{hrs}$ PC. At $48 \mathrm{hrs}$ PC in group II mice showed profound depression with appreciable swelling, enlargement, and reddish discoloration with extravasations of blood stained exudates; at 72 and 120 hrs mortality was $60 \%$. On the contrary in group III treated mice there were little inflammatory changes at 48 and $72 \mathrm{hrs} \mathrm{PC}$, with signs of recovery at $120 \mathrm{hrs} \mathrm{PC;} \mathrm{similarly} \mathrm{mild}$ inflammatory changes in mammary gland could be observed at 48 and $72 \mathrm{hrs}$ PC in group IV mice with recovery at $120 \mathrm{hrs}$ PC (Table 2).

3.3. DLC in Blood. DLC was done in all groups at $0 \mathrm{hr}, 24 \mathrm{hrs}$, $48 \mathrm{~h}, 72 \mathrm{hrs}$, and $120 \mathrm{hrs}$ post challenge, respectively. At $0 \mathrm{hr}$ lymphocyte count was more and neutrophils count was lesser in all the 4 groups, whereas neutrophil count increased and lymphocyte count decreased significantly in all the infected groups (group II, group III, and group IV) as compared to healthy group (group I) at $24 \mathrm{hrs} \mathrm{PC.} \mathrm{In} \mathrm{group} \mathrm{II} \mathrm{animals}$ the mean neutrophil count increased to an extent of $66.07 \%$ at $120 \mathrm{hrs}$ PC as compared to $0 \mathrm{hr}$ count. Similarly in group III and group IV significantly higher count to an extent of $48.6 \%$ and $40.6 \%$ could be observed at $24 \mathrm{hrs}$, respectively; however the neutrophil count at $48 \mathrm{~h}, 72 \mathrm{hrs}$, and $120 \mathrm{hrs}$ PC did not differ significantly, whereas the lymphocyte counts in group II animals decreased to an extent of $63 \%$ at $120 \mathrm{hrs}$ PC as compared to $0 \mathrm{hr}$ count. Similarly in group III and group IV significantly lower count to an extent of $18.9 \%$ and $31.6 \%$ could be observed at $24 \mathrm{hrs}$, respectively; however the lymphocyte count at $48 \mathrm{hrs}, 72 \mathrm{hrs}$, and $120 \mathrm{hrs}$ PC did not differ significantly (Figure 1).

3.4. CRP in Serum. The CRP was estimated in serum. On day 0 and $120 \mathrm{hrs}$ post challenge the CRP was negative in all groups. Positive CRP was observed in group II at 24, 48, and $76 \mathrm{hrs}$ PC, whereas in group III the CRP positive reaction was recorded at $24 \mathrm{hrs}$ PC only, whilst the CRP reaction was negative in group IV at $24 \mathrm{hrs}$ PC.

3.5. Histopathological Examination. Mice were sacrificed at $120 \mathrm{hrs}$ PC forhistopathological examination of mammary tissue. Tissue sections of mammary gland of group I mice revealed normal healthy lactating alveoli with no signs of inflammation. In group II mice multiple focal micro abscess predominated by neutrophil and fibrinous exudates in the mammary parenchyma was seen with complete disruption of mammary cellular details. In group III receiving astaxanthin, there were few inflammatory cells with no exudation and the tissue structure was normal. Similarly in group IV cellular inflammatory infiltration was mild and mammary parenchyma appeared normal.

\section{Discussion}

So far antibiotics are the only proven method for the treatment of mastitis; however, antibiotic therapy has got several 


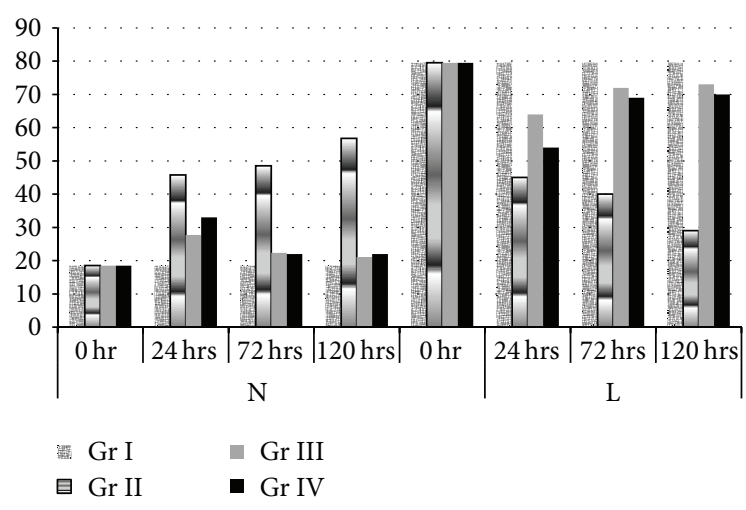

FIGURE 1: Percent neutrophil and lymphocyte in blood in response to the treatment with astaxanthin (group III) and amoxicillin plus sulbactam (group IV) and in positive control (group II) and in normal healthy mice (group I) (mean \pm SE).

demerits including the harmful drug residue in food chain. The clinical efficacy of the nonantibiotic agents is recently being researched extensively with promising results; these include bacterial enzymes, antimicrobial peptides, bioresponse modifiers, cytokines, micronutrients, vitamins, and medicinal herbs $[18,19]$.

Astaxanthin is a xanthophyll carotenoid, naturally obtained from the chlorophyte algae Haematococcus pluvialis [4]. In the present trial the immunotherapeutic effect of astaxanthin (AX) was studied in mice staphylococcal mastitis. In the astaxanthin treated mice, the clinical score was almost normal; in the tissue sections of mammary gland the cellular details were almost normal with negligible infiltration of inflammatory cell and little exudation in H\&E stained section. AX treatment also resisted the intramammary challenge of pathogenic S. aureus; hence no pathological changes could be observed and clinical recovery was $100 \%$. In our experiment AX revealed $26 \mathrm{~mm}$ zone of inhibition against isolated S. aureus. Kumari and Ramanujan [8] also demonstrated the antibacterial activity of AX against $S$. aureus. The CRP is an acute phase protein and is expressed in early stages of infection, acute phase response was higher in post challenge nontreated mice till $72 \mathrm{hrs}$ PC, whereas the CRP was lower in AX treated mice at 48 and $72 \mathrm{hrs} \mathrm{PC}$; it could be due to the anti-inflammatory potential of AX. Astaxanthin is a potent antioxidant and powerful scavenger of free radicals like superoxide and signet oxygen [20]. It suppresses varied inflammatory mediators like TNF- $\alpha$, IL-1 $\beta$, cyclooxygenase2 , and nitric oxide synthase [21, 22]. In the present study the neutrophil count in post challenge nontreated mice was significantly higher, whereas it significantly decreased after 48 hrs PC in AX treated mice. The AX treatment also increased the lymphocyte count; it indicates the immunomodulatory potential of AX. Kurihara et al. [7] demonstrated the immunomodulatory property of astaxanthin; the authors suggested that astaxanthin treatment in diseased mice inhibited the suppressor of NK cell activity and lipid peroxidation.

\section{Conclusion}

In conclusion, this study represents an initial investigation on the therapeutic use of astaxanthin in mice mastitis model challenged with highly pathogenic $S$. aureus. The results of the present study indicate the antibacterial, anti-inflammatory, and immunomodulatory activity of $\mathrm{AX}$ treatment against intramammary challenge with pathogenic bacteria. AX treatment significantly reduced the neutrophil count and acute phase protein and enhanced the lymphocyte count and improved early clinical recovery with no pathological changes in the mammary parenchyma. The present drug trial determines the potential benefits of the AX therapy in intramammary infection in mice model as well as standardization of nonantibiotic agent to reduce antibiotic residue from food chain.

\section{Conflict of Interests}

The authors declare that there is no conflict of interests regarding the publication of this paper.

\section{Acknowledgments}

Tshering Dolma is thankful to Indian Council of Agriculture Research, New Delhi, for providing the financial assistance in form of Junior Research Fellowship. Authors are also thankful to the director of the institute for providing the facilities.

\section{References}

[1] S. Taponen and S. Pyörälä, "Coagulase-negative staphylococci as cause of bovine mastitis-Not so different from Staphylococcus aureus?" Veterinary Microbiology, vol. 134, no. 1-2, pp. 29-36, 2009.

[2] D. C. Oliveira, S. W. Wu, and H. De Lencastre, "Genetic organization of the downstream region of the mecA element in methicillin-resistant Staphylococcus aureus isolates carrying different polymorphisms of this region," Antimicrobial Agents and Chemotherapy, vol. 44, no. 7, pp. 1906-1910, 2000.

[3] WHO, Antimicrobial resistance: global report on surveillance, 2014, http://www.who.int/drugresistance/en/.

[4] M. Olaizola and M. E. Huntley, "Recent advances in commercial production of astaxanthin from microalgae," in Biomaterials and Bioprocessing, M. Fingerman and R. Nagabhushanam, Eds., Science Publishers, 2003.

[5] Y. Ikeda, S. Tsuji, A. Satoh, M. Ishikura, T. Shirasawa, and T. Shimizu, "Protective effects of astaxanthin on 6-hydroxydopamine-induced apoptosis in human neuroblastoma SH-SY5Y cells," Journal of Neurochemistry, vol. 107, no. 6, pp. 1730-1740, 2008.

[6] M. Bennedsen, X. Wang, R. Willén, T. Wadström, and L. P. Andersen, "Treatment of $H$. pylori infected mice with antioxidant astaxanthin reduces gastric inflammation, bacterial load and modulates cytokine release by splenocytes," Immunology Letters, vol. 70, no. 3, pp. 185-189, 2000.

[7] H. Kurihara, H. Koda, S. Asami, Y. Kiso, and T. Tanaka, "Contribution of the antioxidative property of astaxanthin to its protective effect on the promotion of cancer metastasis in 
mice treated with restraint stress," Life Sciences, vol. 70, no. 21, pp. 2509-2520, 2002.

[8] U. Kumari and R. Ramanujan, "Isolation of astaxanthin from shrimp metapenaeus dobsoni and study of its pharmacological activity," Journal of Current Chemical and Pharmaceutical Science, vol. 3, no. 1, pp. 60-63, 2013.

[9] NCCLS, "Performance standards for antimicrobial susceptibility testing, 9th informational supplements," Document M100S9, NCCLS, Wayne, Pa, USA, 1999, (vol. 19, no. 1, Table 21).

[10] L. A. Chitwood, "Tube dilution antimicrobial susceptibility testing: efficacy of a microtechnique applicable to diagnostic laboratories," Applied Microbiology, vol. 17, no. 5, pp. 707-709, 1969.

[11] J. H. Jorgensen, "Selection criteria for an antimicrobial susceptibility testing system," Journal of Clinical Microbiology, vol. 31, no. 11, pp. 2841-2844, 1993.

[12] O. W. Schalm and D. O. Noorlander, "Experiments and observations leading to development of the California mastitis test," Journal of the American Veterinary Medical Association, vol. 130, no. 5, pp. 199-204, 1957.

[13] T. K. Griffin, F. H. Dodd, F. K. Neave, D. R. Westgarth, R. G. Kingwil, and C. D. Wilson, "A method of diagnosing intramammary infection in dairy cows for large experiments," Journal of Dairy Research, vol. 44, no. 1, pp. 25-45, 1977.

[14] R. Cruickshank, Mackie and Mc Cartney's Handbook of Bacteriology, E \& S.Livingstone limited, Edinburgh, UK, 10th edition, 1962.

[15] A. A. Miles, S. S. Misra, and J. O. Irwin, "The estimation of the bactericidal power of the blood," The Journal of Hygiene, vol. 38, no. 6, pp. 732-749, 1938.

[16] Sridevi, Studies on isolation, characterization and therapeutic use of bacteriophages against Streptococcus agalactiae associated with ruminant mastitis [M.V.Sc. thesis], Indian Veterinary Research Institute, Izatnagar, India, 2005.

[17] N. C. Jain, Schalm's Veterinary Hematology, Lea and Febrriger, Philadelphia, Pa, USA, 4th edition, 1986.

[18] R. Mukherjee, G. C. Ram, P. K. Dash, and T. Goswami, "The activity of milk leukocytes in response to a water-soluble fraction of Mycobacterium phlei in bovine subclinical mastitis," Veterinary Research Communications, vol. 28, no. 1, pp. 47-54, 2004.

[19] R. Mukherjee, P. K. Dash, and G. C. Ram, "Immunotherapeutic potential of Ocimum sanctum (L) in bovine subclinical mastitis," Research in Veterinary Science, vol. 79, no. 1, pp. 37-43, 2005.

[20] S. Goto, K. Kogure, K. Abe et al., "Efficient radical trapping at the surface and inside the phospholipid membrane is responsible for highly potent antiperoxidative activity of the carotenoid astaxanthin," Biochimica et Biophysica Acta, vol. 1512, no. 2, pp. 251-258, 2001.

[21] K.-E. Eilertsen, H. K. Mæhre, I. J. Jensen et al., "A wax ester and astaxanthin-rich extract from the marine copepod Calanus finmarchicus attenuates atherogenesis in female apolipoprotein E-deficient mice," The Journal of Nutrition, vol. 142, no. 3, pp. 508-512, 2012.

[22] S.-J. Lee, S.-K. Bai, K.-S. Lee et al., "Astaxanthin inhibits nitric oxide production and inflammatory gene expression by suppressing I $\kappa \mathrm{B}$ kinase-dependent NF- $\kappa \mathrm{B}$ activation," Molecules and Cells, vol. 16, no. 1, pp. 97-105, 2003. 

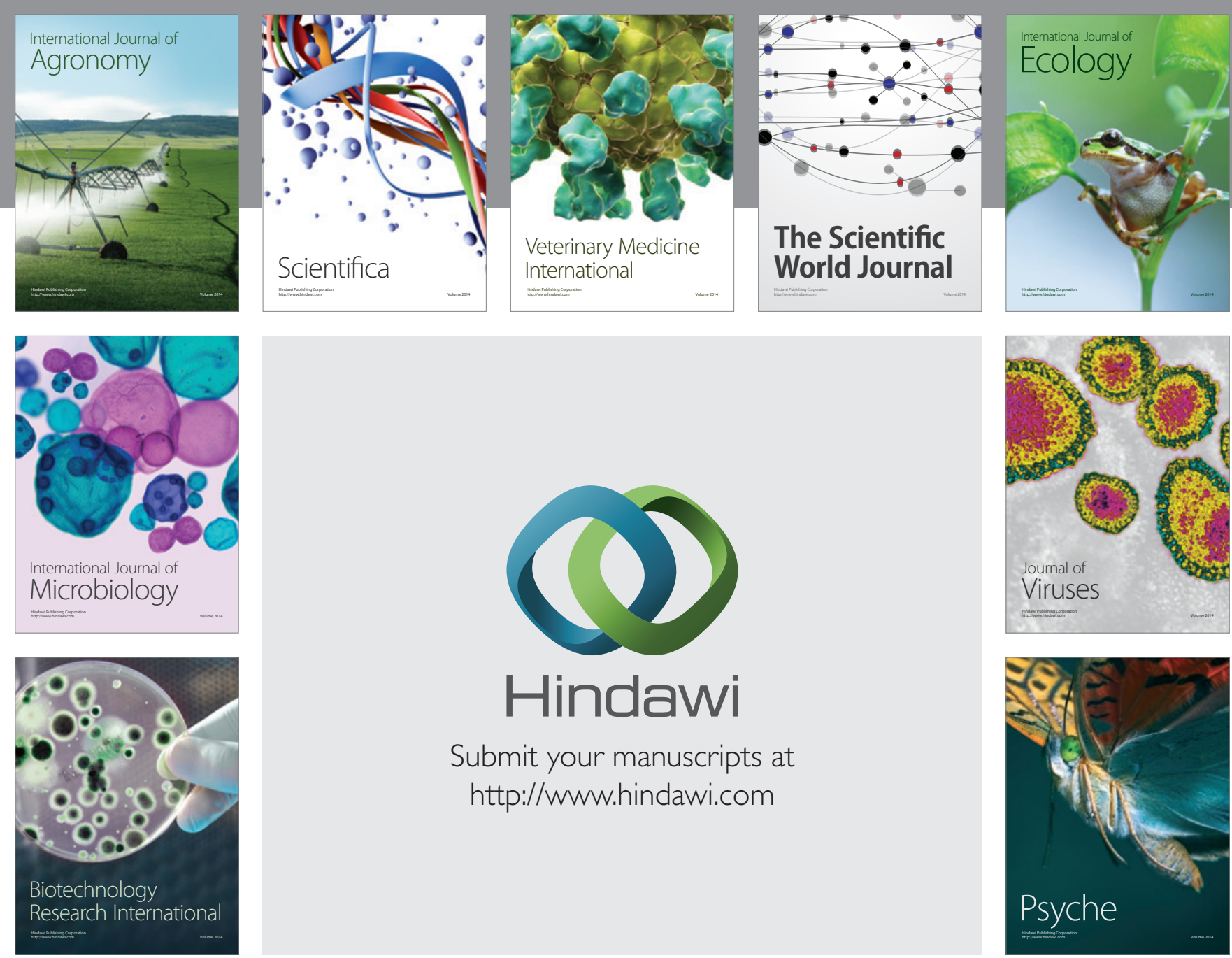

Submit your manuscripts at http://www.hindawi.com
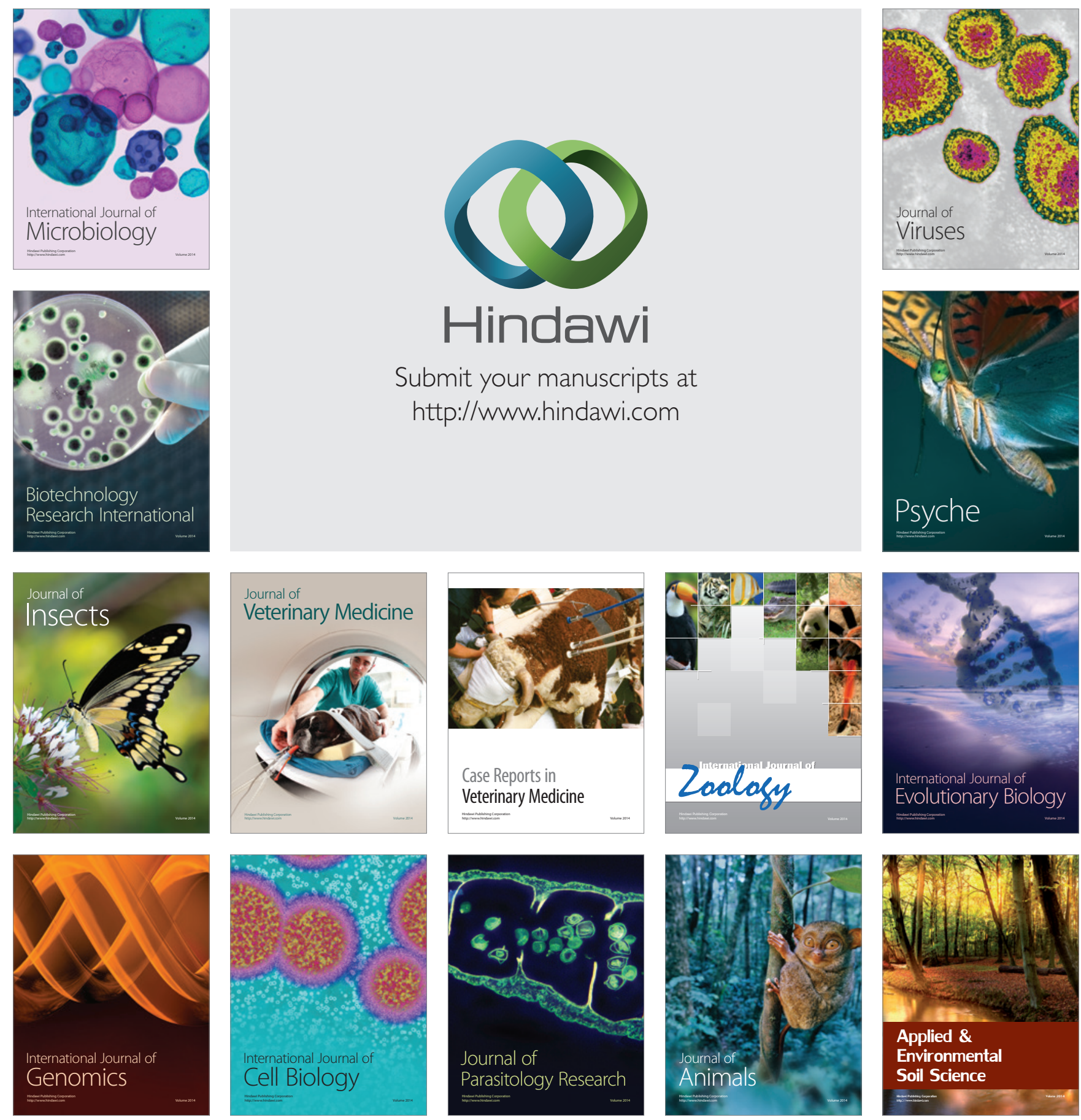